\title{
EMPOWERMENT OF WOMEN THROUGH ENTREPRENEURSHIP: A STUDY IN GUWAHATI CITY OF ASSAM
}

\author{
Debashree Kashyap \\ Research Scholar, Department of Economics, \\ Gauhati University, Assam, India \\ Jayashree Bordoloi \\ Research Scholar, Department of Business Administration, \\ Tezpur University, Assam, India
}

\begin{abstract}
The status of women in any society is the best way to understand its civilization. But Indian history demonstrates that women are the victims of all sorts of deprivation. In spite of the various welfare related activities for women, illiteracy and ignorance about their rights are still prevalent among majority of the women in India. So, in the last few decades the issue of empowerment of women has been acknowledged as an important tool of reducing their plight and improving their lives in the country. In the context of women empowerment, entrepreneurship plays an important role because entrepreneurship offers various opportunities for women by opening the doors to greater self-sufficiency and self-esteem not only for the women themselves, but also for their families. Over the years it is seen that the hidden entrepreneurial potentials of women have gradually developed among women in Assam. The progress is mostly seen among the women in urban areas. So, this study is an attempt to identify the motivational factors that influences the women entrepreneurs to start their own enterprises. Further, the study highlights the impact of socio-economic factors including enterprise related factors on empowerment of women entrepreneurs in the City. It is found that monthly income from enterprises plays an important role in achieving economic empowerment of women in the study area.
\end{abstract}

Key words: Women, Empowerment, Entrepreneurship, Motivational Factors.

Cite this Article: Debashree Kashyap and Jayashree Bordoloi, Empowerment of Women through Entrepreneurship: A Study in Guwahati City of Assam, International Journal of Management, 11(12), 2020, pp 717-724.

http://iaeme.com/Home/issue/IJM?Volume=11\&Issue=12 


\section{INTRODUCTION}

The status of women in any society is the best way to understand its civilization. But Indian history demonstrates that out of all deprived groups in the society women have suffered the most. They are the victims of all sorts of deprivation. In spite of the various welfare related activities for women, illiteracy and ignorance about their rights are still prevalent among majority of the women in India. So, in the last few decades the issue of empowerment of women has been acknowledged as an important tool of reducing their plight and improving their lives in the country. Women empowerment is a multi-dimensional process. It is a process that helps women to realize their identity, raise their voice against injustice, exploitation and violence. It ensures women's participation in all walks of life. The International Women's Conference in 1985 at Nairobi defined women empowerment as "A redistribution of social power and control of resources in favour of women." Women empowerment is also defined as "a change in the context of a women's life, which enables her increased capacity for leading a fulfilling human life. It gets reflected in external qualities such as health, mobility, education and awareness, status in the family, participation in decision making and also at the level of material security. It also includes internal qualities such as self awareness and self confidence."[Mathew(2003)]

In the context of women empowerment, entrepreneurship plays an important role. Entrepreneur is a person who creates an enterprise. The process involved in the creation of enterprise is called entrepreneurship. On the basis of general concept of entrepreneur, women entrepreneur can be defined as a woman or group of women who initiate, organise and run a business enterprise. A woman entrepreneur is an important constituent of the development process. Entrepreneurship offers various opportunities for women by opening doors to greater self-sufficiency and self-esteem not only for the women themselves, but also for their families. Entrepreneurship development among women is one of the most important factors to achieve economic empowerment of women. Women Entrepreneurship can bring about economic independence to women and improve their status in the society. Equality among men and women which is essential for the development of a society can possible through economic independence of women. When a woman entrepreneur creates an enterprise, it generates income, employment and create wealth. So, the contributions of women entrepreneurs are a prerequisite for nation building and it is very important to encourage women to take up entrepreneurship as a career. Though women face a number of challenges and obstacles in establishing enterprises, women entrepreneurship and formation of women business networks are steadily rising. Over the years it is seen that there is a considerable development of women entrepreneurship in Assam. Women are increasingly taking up entrepreneurial career for improving their economic as well as social status and also for fulfilling their creative urge. Hence, in this paper an attempt is made to study the motivational factors that influences the women entrepreneurs to start their own enterprises, to study the role of socio- economic variables including enterprise related variables on empowerment of women entrepreneurs and also to study the relationship between enterprise related factors and success of women entrepreneurs in Guwahati city of Assam.

\section{REVIEW OF LITERATURE}

Sinha (2003) had examined the impact of motivation and social support on enterprise creation by women in North-East India. The results of the study had revealed that the main motivating factor to start an enterprise was to earn money by women entrepreneurs. The enterprises set up by them were mostly micro enterprises. It was found that the women entrepreneurs were predominantly engaged in traditional activities such as handicrafts and handloom. The units of both men and women entrepreneurs were suffering from inadequate income generation. 
Majority of women entrepreneurs managed finance through their own sources. However, the study concluded that women of the region had enough potential to take up entrepreneurship as a career. Deshpande and Sethi (2009) had made an attempt to identify the problems encountered by women in setting of enterprises and also to provide solutions to various problems faced by women entrepreneurs. The authors had found that women were participating in entrepreneurship because of attitude change, support and co-operation by society members, changes and relaxation in Government policies. But there is also a need to create awareness among women to outshine in entrepreneurial field. Das (2012) had conducted a study on women empowerment through entrepreneurship in Guwahati Municipal Corporation. The author had examined the attitude of family and society towards women entrepreneurs and also studied the problems faced by them. The findings revealed that women entrepreneurs got gainful employment in the units established by them. Moreover, enterprises headed by women also generated employment for a number of persons. Findings also revealed that women entrepreneurs considered finance as a major problem and marketing was the next problem faced by them. Limbu and Bordoloi (2015) had conducted a study on women entrepreneurship and the problems and opportunities for rural women in the area of entrepreneurship in Assam. The study found that the rural women entrepreneurs were suffering from individual problems such as lack of motivation, inadequate financial resources, technical problem, physical insecurity problem and a variety of social and structural problems. Though there was lots of problems that were creating hurdles for the women entrepreneurship in rural Assam, the author had found that prospects of growth of entrepreneurship in rural areas of Assam could not be underestimated.

\section{OBJECTIVES OF THE STUDY}

The present study is carried out with the following objectives:

1. To study the motivational factors that affect the women entrepreneurs to start their own enterprises.

2. To study the relationship between enterprise related factors and success of women entrepreneurs.

3. To study the role of socio- economic variables including enterprise related variables on empowerment of women entrepreneurs.

\section{METHODOLOGY}

The study is done by using survey method. Sample for the present study is drawn by using purposive sampling method. The sample of the present study consists of 70 women entrepreneurs engaged in registered and unregistered enterprises in Guwahati city. The study is solely based on the primary data collected from the respondents with the help of questionnaire. For the present study, the questionnaire is designed to get information on the types of enterprises, motivational factors, experience, assets, investment level, income etc. Questionnaire also includes 13 statements constructed on Likert scale in which the respondents have to choose out of the five responses. The collected primary data are analysed by using likert scale, rank, chi-square test and regression model. 


\section{FINDINGS}

\subsection{Motivational Factors}

Motivation plays a very important role in the development of entrepreneurial activities. In this study, motivational factor is defined as influencing factor that inspire women to start their own enterprises to achieve their goals. Entrepreneurial motivation probably the starting point to start an enterprise, which provides direction, energy and tendency to act. So, in this study an attempt is made to identify the motivational factors behind the women entrepreneurs for pursuing entrepreneurship.

On the basis of research studies on motivational factors, 13 statements are chosen. A scale to measure motivational factors is constructed covering the 13 statements which are related to personal, economic and social factors and these statements are constructed on Likert five point scale. Scores are given according to the degree of the responses. The responses are- Not at all-1, A little bit-2, To some extent-3, To a large extent-4, To full extent-5. The total score of each woman entrepreneur is obtained by adding the scores of all the individual items in that scale. After that mean value of each statements is calculated. The responses of the 70 respondents on the statements regarding motivational factors are shown in the Table 1.

Table 1 Motivating Factors

\begin{tabular}{|l|c|c|}
\hline \multicolumn{1}{|c|}{ Statements/Motivating factors } & Mean Score & Rank \\
\hline 1. Own interest and personal freedom & 4.12 & 2 \\
\hline 2. To be self dependent & 4.36 & 1 \\
\hline 3. Encouragement from family & 3.69 & 5 \\
\hline 4. Not getting a government job & 4.12 & 2 \\
\hline 5. Willing to do something creative & 3.80 & 4 \\
\hline 6. Availability of raw material & 4.12 & 2 \\
\hline 7. Good market potential & 4.12 & 2 \\
\hline 8. To utilize own skill & 3.63 & 6 \\
\hline 9. To get better status/recognition in society & 3.36 & 7 \\
\hline 10. Role model to others & 3 & 8 \\
\hline 11. Economic need & 4.12 & 2 \\
\hline 12. To support household expenditure & 2.97 & 9 \\
\hline 13. Desire to give employment opportunity/financial security to others & 4 & 3 \\
\hline
\end{tabular}

Motivational factors for taking up entrepreneurship as a career varied from person to person. The data presented in the Table 1 shows the ranking of different statements on the basis of mean scores. From Table 1, it is seen that women entrepreneurs have different motivation to start their own enterprises. The findings shows that desire for self dependent influenced significantly the women entrepreneurs to select entrepreneurship as a career and this factor has the highest mean score of 4.36 and occupy first position. Own interest and personal freedom, availability of raw material, good market potential, not getting a government job and economic need occupies second position. Desire to give employment opportunity/financial security to unemployed women to balance their life, willing to do something creative, encouragement from family, to utilize own skill, to get better status/recognition in society, role model to others and to support household expenditure occupies third, fourth, fifth, sixth, seventh, eighth and ninth position respectively.

\subsection{Types of Enterprises and Enterprise Related Factors}

The women entrepreneurs are engaged in manufacturing and service enterprises. Under manufacturing enterprises, women are engaged in jewellery making and weaving business. In 
case of service type of enterprises, women are engaged in beauty parlour and restaurant. Success of women entrepreneurs can be attributed to the experience of entrepreneurs, assets, investment level, employment and monthly income of the entrepreneurs from their enterprises. In the present study an attempt is also made to find out the relationship between the above mentioned enterprise related factors and success of women entrepreneurs in the selected study area.

Table 2 Enterprise Related Factors

\begin{tabular}{|l|l|c|c|}
\hline \multicolumn{1}{|c|}{ Factors } & \multicolumn{1}{|c|}{ Particular } & $\begin{array}{c}\text { Number of } \\
\text { Respondents }\end{array}$ & Percentage \\
\hline Types of enterprises & Manufacturing & 35 & 50 \\
& Service & 35 & 50 \\
\hline Experience & Less than 15 years & 33 & 47.14 \\
& Above 15 years & 37 & 52.86 \\
\hline Assets & Up to 10 lakhs & 31 & 44.29 \\
& Above 10 lakhs & 39 & 55.71 \\
\hline Investment level & Less than 2 lakhs & 34 & 48.57 \\
& Above 2 lakhs & 36 & 51.43 \\
\hline Monthly income from & Up to 25 thousand & 38 & 45.71 \\
enterprise & Above 25 thousand & 33 & 54.29 \\
\hline Employment & Less than 20 member & 37 & 47.14 \\
& Above 20 member & 52.86 \\
\hline
\end{tabular}

$50 \%$ of the women entrepreneurs own manufacturing enterprises and $50 \%$ of the women entrepreneurs own service enterprises. In case of experience, $47.14 \%$ of the women entrepreneurs have less than 15 years of experience and $52.86 \%$ of the women entrepreneurs have more than 15 years of experience. $44.29 \%$ of the entrepreneurs own assets up to 10 lakhs and $55.71 \%$ own assets more than 10 lakhs. It is found that $48.57 \%$ of entrepreneurs have invested less than 2 lakhs in their business and 51.43\% have invested more than 2 lakhs in their business. $45.71 \%$ have reported that their approximate monthly income from their business is less than 25 thousand and it is found that majority $(54.29 \%)$ of the women entrepreneurs have earned more than 25 thousand per month from their business. $47.14 \%$ of the women entrepreneurs are providing employment to less than 20 persons and $52.86 \%$ of the entrepreneurs are proving employment to more than 20 persons.

In order to study the relationship between enterprise related factors and success of women entrepreneurs in Guwahati city, Chi-square test is conducted by using the following hypotheses.

$\mathrm{H}_{0}$ : There is no significant relationship between enterprise related factors and success of women entrepreneurs in Guwahati city.

$\mathrm{H}_{1}$ : There is significant relationship between enterprise related factors and success of women entrepreneurs in Guwahati city.

Table 3 Enterprise related factors and success of women entrepreneurs

\begin{tabular}{|l|c|c|c|}
\hline \multirow{2}{*}{ Factors } & \multicolumn{3}{|c|}{ Level of Success (High, Medium and Low) } \\
\cline { 2 - 4 } & $\begin{array}{c}\text { Calculated Chi-square } \\
\text { Value }\end{array}$ & Df & $\begin{array}{c}\text { Null Hypotheses } \\
\text { Accepted/Rejected }\end{array}$ \\
\hline Types of enterprises & 11.88 & 2 & Rejected \\
\hline Experience & 16.76 & 2 & Rejected \\
\hline Assets & 11.28 & 2 & Rejected \\
\hline Investment level & 10.97 & 2 & Rejected \\
\hline $\begin{array}{l}\text { Monthly income from } \\
\text { enterprise }\end{array}$ & 17.41 & 2 & Rejected \\
\hline Employment & 18.53 & 2 & Rejected \\
\hline
\end{tabular}


From the Chi-square test, it is found that there is significant relationship between enterprise related factors and success of women entrepreneurs in Guwahati city. So, it leads to the rejection of all null hypotheses. It indicates that enterprise related factors have a significant impact on the success of women entrepreneurs in the study area.

\subsection{Empowerment of Women through Entrepreneurship}

Empowerment of women is of prime importance as they form almost half of the human resources of our state. Without their involvement in the development process, the growth and development cannot be achieved. Women empowerment is a multi-dimensional concept. It is a process that makes women self-reliant, economically productive, socially active and helps to make decisions which realize their identity. Women empowerment is achieved when women attain the power to control freely over physical, intellectual and financial resources. Empowerment of women has various dimensions. Social dimensions of women empowerment relates to reputable and non-discriminatory position of women in the society. Political dimensions of women empowerment relates to the involvement of women in the governance of nation from grassroots to top level. Economic dimensions of women empowerment shows the equality of opportunities in employment, wages and other economic resources. So, promotion of empowerment of women in all these dimensions is very essential to promote developmental activities. In this context, entrepreneurship can be used as an important tool to promote women empowerment because through the entrepreneurship as a career women are empowered to show their decision making power in economic, political and social spheres. So, in this section an attempt is made to study the role of socio- economic variables including enterprise related variables on empowerment of women entrepreneurs. For this, Women Empowerment Index (WEI) is constructed by including different dimensions of household decision making power for each entrepreneur by using the following dimension index:

WEI= (Actual Value-Minimum Value)/(Maximum Value-Minimum Value)

In this study, 9 different indicators of the household decision making power by women entrepreneurs is taken such as purchase of daily household needs, purchase of durable consumer goods, visit to relatives, decision regarding family planning, decision regarding education of children, usage of own income, decision regarding saving, exposure to media and own health care in four statements such as (1) She takes decision solely, (2) She decides jointly with family members, (3) She takes decision by consulting others, (4) She does not take decision. In order to construct WEI for each indicator above formula is used for each surveyed women entrepreneurs.

Further, following regression model is estimated to study the effect of socio- economic variables including enterprise related variables on WEI.

$\mathrm{Y}_{\mathrm{t}}=\mathrm{a}_{\mathrm{o}}+\mathrm{a}_{1} \mathrm{X}_{1 \mathrm{t}}+\mathrm{a}_{2} \mathrm{X}_{2 \mathrm{t}}+\ldots \ldots .+\mathrm{a}_{8} \mathrm{X}_{8 \mathrm{t}}+\mathrm{U}_{\mathrm{t}}$

Where, $\mathrm{Y}_{\mathrm{t}}=\mathrm{WEI}, \mathrm{X}_{1}=$ Age, $\mathrm{X}_{2}=$ Marital Status, $\mathrm{X}_{3}=$ General Education (in years), $\mathrm{X}_{4}=$ Technical Education (in years), $\mathrm{X}_{5}=$ Type of Enterprise (Manufacturing/Service), $\mathrm{X}_{6}=$ Whether take Sales Promotion Measure (Yes/No), $\mathrm{X}_{7}=$ Assets (in rupees), $\mathrm{X}_{8}=$ Monthly Income from Enterprise. 
Results of regression are shown in the following table.

Table 4 Effect of Socio-economic Factors Including Enterprise Related Factors on WEI.

\begin{tabular}{l|l|c|c|}
\hline \multicolumn{1}{|c|}{ Factors } & Coefficients & t-value & p-value \\
\hline Intercept & 0.33764 & 2.03678 & 0.041344 \\
\hline Age & 0.00565 & 2.06307 & $0.030866^{* *}$ \\
\hline Marital Status & 0.03675 & 0.57423 & 0.564937 \\
\hline General Education & -0.01845 & -0.17684 & 0.664542 \\
\hline Technical Education & 0.07215 & 2.52379 & $0.015645^{* *}$ \\
\hline Type of Enterprise & 0.03876 & 0.76264 & 0.465264 \\
\hline $\begin{array}{l}\text { Whether take Sales } \\
\text { Promotion Measure }\end{array}$ & 0.01653 & 0.43673 & 0.631403 \\
\hline Assets & 0.062056 & 1.32572 & 0.265305 \\
\hline $\begin{array}{l}\text { Monthly Income from } \\
\text { Enterprise }\end{array}$ & 0.06401 & 2.95130 & $0.034123^{* *}$ \\
** indicates 5\% level of significance & & & \\
\hline
\end{tabular}

From the regression outcome, it is revealed that age, technical education and monthly income from enterprise are statistically significant at 5\% level of significance. It means that these three factors significantly affect women empowerment index of different household decision makings. Age of the women entrepreneurs significantly affect their decision at the household level. Women entrepreneurs who have higher age are more empowered than women entrepreneurs who have lower age so that they can take their own decisions independently. It is also found that women entrepreneurs who have higher technical education are more empowered in their decision making power as they endowed with specific skill, knowledge which helps them to become a successful entrepreneur. Another factor which significantly affect WEI of household decisions is monthly income from enterprise. It means that women entrepreneurs with higher monthly income can take decisions in their household more independently than women entrepreneurs with lower monthly income. From this, it can be said that women entrepreneurship acts as a tool of economic empowerment of women in the study area.

\section{CONCLUSION}

From the above discussion, it is found that women entrepreneurship plays a prime role in the economic empowerment of women in the Guwahati City. Moreover, the contribution of the women entrepreneurs to the economy of the City cannot be underscored. Entrepreneurship among women not only improves the wealth of the public but also improves the wealth of the family. So, the survivor and growth of the enterprises headed by women are very essential for the success of women entrepreneurs. For the future success of an enterprise own by women, the women entrepreneurs could be trained and educated properly with regard to selecting the type of enterprises, creation of assets and access to capital and women entrepreneurs can opt for effective delegation of work and smart decisions so that they can utilize their time and entrepreneurial skills for overall growth of their enterprises.

\section{REFERENCES}

[1] Das, M. (2012) 'Women Empowerment through Entrepreneurship: A Case Study of Guwahati Municipal Corporation', International Journal of Computer Applications in Engineering Sciences, 2(1), pp. 27-29

[2] Deshpande, S and Sethi, S. (2009) 'Women Entrepreneurship in India', International Research Journal, 2(9-10), pp. 13-17 
[3] Danabakyam, M and Kurian, S. (2012) 'Women Entrepreneurship in Micro, Small and Medium Enterprises (MSME) in Chennai City', International Journal of Marketing, Financial Services \& Management Research, 1(10), pp. 68-74

[4] Limbu, S and Bordoloi, N. (2015) 'Women Entrepreneurship: Problems and Prospects in Rural Assam', International Journal of Interdisciplinary Research in Science Society and Culture, 1(1), pp. $117-125$

[5] Saikia, P. (2017) 'Motivational Factors and Empowerment of Women Entrepreneurs in Assam: An Exploratory Study', Indian Res. J. Ext. Edu., 17(4), pp. 87-92

[6] Sharma, P. (2013) 'Women Entrepreneurship Development in India', Global Journal of Management and Business Studies, 3(4), pp. 371-376

[7] Sinha, P. (2003) 'Women Entrepreneurship in North East India: Motivation, Social Support and Constraints', Indian Journal of Industrial Relations, 28(4), pp. 425-441

[8] Human Development Indices and Indicators (2018), Statistical Update

[9] Madan, S., Gulyani, M. and Benson, S. (2014) 'Women Empowerment through Entrepreneurship', International Journal of Engineering and Management Research, 4(6), pp. 86-89

[10] Mathew, G (2003), Keynote address in the workshop on "A Decade of Women's Empowerment through Local Governance" organized jointly by Institute of Social Sciences and South Asia Partnership, Canada sponsored by International Development Research Centre

[11] Gupta, S (2014) 'Impact of Economic Development on Status of Women: An Analysis for India', International Journal of Business and Management Invention, 3(2), pp. 23-29 